\title{
Teaching English Listening from the Perspective of Flipped Classroom
}

\author{
Na Zeng \\ School of Foreign Languages \\ China West Normal University \\ Nanchong, China \\ E-mail: nanazeng2000@163.com
}

\begin{abstract}
In many of the college English listening classrooms across the country, students are passively engaged in class listening tasks and their class performance needs to be improved. This study seeks to bring about improvements in student engagement and performance in the college English listening classroom through the implementation of the flipped model of instruction. Flipped classrooms reverse traditional lecturing because students learn contents before dass through readings and prerecorded contents, freeing lectures for problem-solving activities and discussion. The proposed framework discusses problems of English listening teaching in traditional classrooms and puts forward the model of flipped listening classrooms to facilitate the listening class. We hope that this study will shed light on critical issues in understanding teaching English listening with the model of flipped classrooms and in scaling up its implementation in college education.
\end{abstract}

Keywords—teaching; English listening; flipped classroom

\section{INTRODUCTION}

With the introduction of Communicative Language Teaching in the 1970s, teaching English for communicative purposes became highlighted around the world, and the significance of listening comprehension started to rise (Morley, 2001). Listening is now accepted as the heart of a language because it provides input for the learner and listening exercises provide teachers with a tool for drawing learners' attention to new forms (vocabulary, grammar, new interaction patterns) in the language (Vandergrift, 2007).

Substantial roles it has played though, listening had been one of the most neglected skills in English language teaching. Just as Nunan (1999), Flowerdew and Miller (2005) put it, listening is the "Cinderella" of the four language skills. Language teachers paid more attention to reading and grammatical skills and teaching listening was not accepted as a significant feature of the language learning process (Richards \& Rodgers, 2001); instead it served as a means of introducing new grammar through model dialogues (Field, 2008). Students only receive passively what their teachers want them to listen in a traditional English listening class where teachers value "how to teach" more than "how students should comprehend the meaning". In a study conducted by Goh (2000), listening problems of a group of
Chinese students learning English as foreign language are identified as follows: quickly forget what is heard, not recognizing words already known, understanding words but not the intended message, neglecting the next part when thinking about meaning, and being unable to form a mental representation from words heard. Thus in many of the English listening classrooms across the country, students are passively engaged in the content, and their academic performance can be described, at best, as mediocre.

The flipped classroom, although a relatively new model of practice in China, appears to be gaining momentum and is well-received. By moving the lecture outside the classroom via technology and moving homework and exercises with concepts inside the classroom via learning activities, this new teaching strategy gives language teachers new insights into the way they teach listening and the way students improve their listening comprehension.

\section{PROBLEMS OF TEACHING ENGLISH LISTENING IN TRADITIONAL LECT URE SETTINGS}

As a language skill, listening has been defined by The International Listening Association (1996) as the process of receiving, constructing meaning from and responding to spoken and/or nonverbal messages. Rost (2002) suggests that listening is vital in the language classroom because spoken language provides a means of interaction for learners, and learners must interact to achieve understanding. Besides, authentic spoken language presents a challenge for the learner to understand language in the way it is actually used by native speakers.

Although the importance of listening skills is widely acknowledged in China, the adequate teaching and materials to develop them have not been provided. In a traditional English listening classroom, the listening assignment turned out to be long lifeless paragraphs that it has become agony for students to hear and for teachers to teach. This pedagogical dilemma can be considered from two aspects: the student factor and the non-student factor.

\section{A. The Student Factor}

By the time Chinese students get into colleges and universities they know approximately 2500 (for the average 
students) to 3000 (for the advanced students) English words. However, they know more words at what I call the "eye level" than they do at the "ear level". When they read the words in print, it is easy for them to get the meaning. When they are given a material to listen, however, even the same words seem completely new to them. Actually in any given listening material, students will be faced with three general types of words: those which are completely strange, those for which there is a nodding acquaintance, and those that are known well. It is interesting to point out that the words which they find completely new are not the greatest obstacle which stands in their way to the understanding of a listening material. Words students take for granted or thought they have already known are their biggest problems. Of the words the students have a casual knowledge of, along with those known well, there is a certain percentage which will be known and recognized at the "eye level" but that will be complete strangers at the "ear level". Thus, there are words which are familiar to the student when in print, but which are quite unfamiliar when turned into speech.

\section{B. The Non-student Factor}

As far as the non-student factor is concerned, the current situation of teaching English listening in Chinese colleges can be viewed from three aspects. In a typical listening lesson, students are asked to listen to the recorded script of a reading textbook and after listening to some materials, they are supposed to answer some designed questions (including some multiple choice questions, true or false questions, or problem-solving questions) based on the content of listening materials. Correct answers are emphasized in this kind of lesson, but the listening process necessary to decode the information is ignored and the kinds of skills and strategies for effective listening are not practiced. It is easy to notice that under this classroom setting, students are just tested on their own ability to answer correctly and are not taught how to listen to English. In the long run, average students would lose heart and advanced students would find it really dull in listening class.

Second, the amount of time for listening lessons is limited in English listening, compared with reading, writing, and speaking. Four periods of class time is given to Chinese college students of non-English majors. Of the four periods of time, at least half is assigned to reading and writing. And in listening class, because of the time limit, teachers are pressured to race against the clock to fin ish the teaching tasks, leaving a pile of questions students feel confused about.

Third, students are not sufficiently exposed to a variety of authentic materials. Recordings in the listening textbooks may be practiced for students to pass some tests, however, these materials are not the English spoken in the real world. Some students are accustomed to English spoken clearly and slowly in classroom materials and can understand it, but they get embarrassed and frustrated when they encounter real English which is spoken at a normal speed.

\section{BENEFIT S OF FLIPPED CLASSROOMS}

The central vision of the 21 st century schooling is the employment of instructional technology. As Daggett and McNulty (2005) stated, "More extensive scientific and technological advances will occur in the next few years than have happened in the last two centuries. Dealing with these advances requires a different education system from the one in which we were educated." (p. 12). One of the new learning strategies is the student-centered learning and one such student-centered approach is the flipped classroom model of instruction. By moving the lecture outside the classroom via technology and moving homework and exercises with concepts inside the classroom via learning activities, the flipped model of instruction provides a flexible learning approach for students to improve student engagement and performance (Brunsell \& Horejsi, 2011; Tucker, 2012). Though the flipped classroom model of instruction is a relatively new teaching strategy, the benefits of it are becoming more and more obvious. In this research the benefits of flipped classrooms can be explored in two senses: the broad sense and the narrow sense in which teaching English listening is concerned.

\section{A. Benefits in a Broad Sense}

In a broad sense, the flipped classrooms have gained increasing popularity among colleges and universities in the United States because they meet the needs of engaging students where student engagement in higher education is paramount (Coates, 2005). In the flipped classroom learners cover the foundational knowledge at their own pace and then have live interactions and discussions with their classmates and a teacher in face-to-face meetings. According to Steed (2012), flipped classrooms are emerging as one of the latest pedagogical innovations in higher education. Education specialists have discovered that the application of interactive learning experiences and student-centered activities can enrich the learning process in a way the traditional education modes cannot achieve (Zappe, Leicht, Messner, Lit zinger, \& Lee, 2009). The prominent feature of flipped classrooms lies in the use of prerecorded videos as opposed to real-time faceto-face instruction, presenting a form of "service separation" (Keh \& Pang, 2010). In a flipped classroom environment, students are expected to familiarize themselves with class contents (including prerecorded lectures, videos, audio excerpts, readings, and other supplementary learning materials) in their own time so that traditional in-class lecture time can be replaced with interactive activities with their peers and teachers. In so doing, the actual face-to-face contact between lecturers and students is optimized, which greatly encourages the class engagement of students. And when students are engaged with their course content, they are likely to learn more, achieve more, and subsequently do more after in-class time. One of the biggest problems in Chinese college English teaching is the class size. Scholars generally agree that the smaller the class size, the higher students satisfaction ratings of their course experience (Feldman, 1984; McKeachie, 1980; Wachtel, 1998). However, the large population of non-English major class attendants makes it impossible to have class small enough to meet the standard of language teaching, which undoubtedly 
affects student engagement. Fortunately, flipped classrooms can be served as a better educational experience to diminish the negative effect of larger class sizes on student satisfaction for task-based activities, discussions, group work and team learning cater to the mass class.

\section{B. Benefits in terms of Teaching English Listening}

In a narrow sense, flipped classrooms have attributes which are in alignment with the requirements of English listening. First, the free time management of flipped classrooms meets the need of time for English listening. It is widely acknowledged that it takes time to improve a student's listening. The more listening a student practices, the more he or she can understand the language. In traditional listening class, students are required to listen in class and finish the listening exercises, which excused some students from doing some pre-listening tasks, leaving the in-class time a struggle of getting the right answers. However, college students are adult learners who need to be given opportunities to learn autonomously, at their own pace. The flipped classrooms mode requires proper planning on the student's part, so videos, quizzes, discussions, and other activities are completed on time.

Second, the prerecording of lecture content in flipped classroom mode can help students with advanced level as well as the ones with the average level. In traditional listening class, all the students are commanded to listen to the same materials at the same time where the difference in students is greatly neglected. The learning difference in flipped classrooms is that when students prepare their inclass activities, they can be helped with materials suitable for their own competence (which gives higher requirements for the prerecorded materials). When students arrive at their lecture, it is not a traditional instruction mode that they will receive but rather interactions with their class peers and lecturers, so that students will have a better understanding of the listening materials. And the listening process has been monitored naturally because of the push of interactive activities based on the listening materials.

Third, the repeated use of the listening materials can be fulfilled in a flipped classroom environment. The reason why some students know English words at the "eye level" is that they are not exposed to a diverse range of listening materials. Although a large amount of class time is assigned to the listening practice in a traditional classroom, it is still not enough to get the students to know the words at the "ear level". Because the flipped classroom combines the careful prerecording of lecture content with planned in-class activities, it gives students more time to do the listening practice. And this listening practice differs from the prelistening tasks of the traditional classroom in that the former is guided by the teacher's pre-recorded lectures and is taskoriented which is designed to optimize student learning.

\section{BUILDING A NEW MODEL FOR TEACHING ENGLISH LISTENING}

\section{A. A New Mindset}

Self-paced and flipped classroom approaches to learning require both learners and teachers to have a new mindset to make the effective learning and teaching possible. Anything that is different from what we normally do may feel challenging at times. Flipped classrooms in China are relatively new approach to learning and teaching which triggers hot discussion among education researchers and teachers all over the country. However, only a few people find this approach feasible in the real teaching experience and few people set about putting it into practice. That requires perseverance and a positive attitude to adapt to new ways of doing things, making the best of it, and sharing unique insights with others. When the new approach of teaching is put into use, honest feedback is needed from the learners because feedback is an essential tool to ensure the teacher is providing experiences that help learners advance their learning. As a new model for teaching and learning, it is reasonable to imagine that the flipped classroom experience may be more challenging to implement among students who have been accustomed to the learning mode where they are just passive receivers. And we have to realize that since this approach is a student-centered model of education in the digital era, the responsibility of learning should be placed on students themselves and we tutors have to do more in the design of the prerecorded content to get the students more motivated.

\section{B. Design of the Prerecorded Content}

Considering that there are two phases to the flipped classroom: the pre-learning phase and the in-lecture engagement, the design of the pre-recorded content is of vital importance to make learners engaged. To design the prerecorded content, however, some elements should be taken into consideration.

First, the appropriate background knowledge needs to be offered to help learners identify the purpose of the listening activity. According to Long (1989), in the process of comprehending a foreign language, the advantage of activating learners' scripts or schemata in an appropriate situation is obvious. Chiang and Dunkel (1992) explain scripts or schemata as follows: "the written text or spoken discourse does not carry meaning in and of itself. Rather, meaning occurs as a result of the interaction between the reader's or listener's prior knowledge about the world and the text or speech. This world knowledge is rooted in life experiences and enables individuals to make inferences and form expectations about commonplace situations." (p. 350). In other words, since foreign language learners don't have enough linguistic knowledge, they have to predict meaning by activating schemata, thereby compensating for what they cannot decode in speech. Without common schemata or scripts between the speaker and listener, effective communication will not occur. So in the prerecorded content, the teacher should give students short readings or present visual aids which are related to the situation, characters, and 
events of the topic. In this stage, if necessary, some vocabulary should be given. These activities result in stimulating students' interest and making them a ware of the reas on for listening.

Furthermore, guided questions for students of different levels should be provided after they have finished the listening materials. In a traditional clas sroom, all the students are asked the same questions which may seem too difficult for the slow learners or too easy for the advanced students. In the flipped classroom, even though all students are required to listen to the same material, they can choose to answer questions suitable for their own English proficiency. Questions can be divided into beginning, intermediate and advanced level. For example, ask all students to think of an appropriate response to the recorded message. Based on different responses they give, students are guided into different second questions by a video system. And the third question can be done accordingly. The questions can be included from the most general to the most detailed. By doing so, students are encouraged to do more listening to answer the questions within their own capacity and understand more of the listening material before they attend the authentic classroom. This can promote the lecturerstudent interaction in class which is really difficult in the traditional lecture setting.

\section{Guidance in in-class Activities}

Unlike in the traditional classroom where the majority of time is given to listening practice, the in-class time in a flipped classroom is devoted to team work or group work where discussion with peers and lecturers, hands-on activities, debates, or other problem-solving tasks dominate the in-class learning process. The teacher's role as a lecturer in a traditional classroom should be switched to an instructor in a flipped classroom. From this viewpoint, the teacher's guidance is of vital importance to make the in-class activities go smoothly. To guide the learners effectively, priority should be given to the content of these activities. The interactive communication in the flipped classroom is a far cry from what is done in spoken English class because all the in-class activities should be based on the listening materials students have heard. This requires teachers to plan the interactive tasks carefully to cover the content of listening materials.

Another factor that influences the in-class discussion is the completion of the pre-listening tasks. Since the prelistening phase is done out of authentic classroom, the completion of listening materials varies among students. One of the most common questions about flipped learning is "What do I do if my students show up to class and have not viewed the assigned content?" An effective method to ensure that adult learners are prepared is to allow students to selfmoderate their work, preparation, and learning. Students could self-select into discussion groups based on how much they have completed the pre-listening materials. Students who have actively done the pre-listening practice prior to the lecture will be given credit for it and assigned to the discussion group with classmates of the same needs. Similarly, students who do not prepare before class can then come together and would be required to spend some time engaging with content in-lecture in order to then progress to student-centered learning and discussion. In addition to preventing individuals from arriving for authentic classrooms unprepared, a system of filtering out unmotivated learners needs to be established.

\section{CONCLUSION}

The flipped learning model presented in this paper enables instructors to enhance the classroom experience with less lecturing and more activity. It does not simply remove the listening tasks out of the authentic classroom and replace it with in-class communication. The listening tasks should be carefully re-designed and re-arranged to meet the needs of learners with different levels in listening. The design of the pre-recorded materials (including audio or video software or apps, pictures and reading texts closely related to the listening task) is in the hands of teachers, which consequently requires a lot of commitment on the part of teachers. But ultimately, it's up to the learners to trace a plan from where they are to where they want to be, taking advantage of their network and rich amount of information out there. Besides, by pairing students in activity groups, and transitioning lecture time from lecturing to discussion, more engaging learning opportunities can be realized. It is necessary to point out that the in-class activities must be planned and guided with consideration of student engagement and student satisfaction. Flipped classrooms are just means to an end: the optimal learning of English listening. This framework serves as recommendations and paves a road ahead to debate and scholarly discussion about the appropriate and effective approach to English listening teaching. It is hoped that the present study will provide a basis for further studies for the improvements in flipped English listening classrooms in China.

\section{REFERENCES}

[1] J. Morley, "Aural comprehension instruction: Principles and practices," in Teaching English as a second or foreign language, M. Celce Murcia, Eds. Boston: Heinle \& Heinle, 2001, pp. 69-85.

[2] L. Vandergrift, "Recent developments in second and foreign language listening comprehension research," in Cambridge Journals, vol. 40(3), 2007, pp. 191-210.

[3] D. Nunan, Second language teaching and learning. Boston: Heinle \& Heinle, 1999.

[4] J. Flowerdew and L. Miller, Second language listening: Theory and practice. NewYork: Cambridge University Press, 2005.

[5] J. C. Richards and T. S. Rodgers, Approaches and methods in language teaching. Cambridge: Cambridge University Press, 2001.

[6] J. Field, Listening in the language classroom. United Kingdom: Cambridge University Press, 2008.

[7] C. C. M. Goh, "A cognitive perspective on language learners' listening comprehension problems," in System, vol. 28(1), 2000, pp. 55-75.

[8] M. Rost, Teaching and researching listening. Great Britain: Pearson Education, 2002.

[9] W. R. Daggett and R. J. McNulty, "Best practices of high performing high schools," in Leadership, vol. 34(4), 2005, pp. 12-15.

[10] E. Brunsell and M. Horejsi, "Flipping your classroom," in Learning and Leading with Technology, vol. 78(2), 2011, p. 10. 
[11] B. Tucker, "The flipped classroom," in Education Next, vol. 12(1), 2012, pp. 82-83.

[12] H. Coates, "The value of student engagement for higher education quality assurance," in Quality in Higher Education, vol. 11, 2005, pp. 25-36.

[13] A. Steed, "The flipped classroom," in Teaching Business \& Economics, vol. 16(3), 2012, pp. 9-11.

[14] S. Zappe, R. Leicht, J. Messner, T. Litzinger and H. W. Lee, "Flipping the classroom to explore active learning in a large undergraduate course," Paper presented at the American Society for Engineering Education Annual Conference, Portland, Oregon, 2009.

[15] H. T. Keh and J. Pang, "Customer reactions to service separation," in Journal of Marketing, vol. 74, 2010, pp. 55-70.

[16] K. A. Feldman, "Class size and college students' evaluations of teachers and courses: A closer look," in Research in Higher Education, vol. 21(1), 1984, pp. 45-116.

[17] W. J. McKeachie, "Class size, large classes, and multiple sections," in American Association of University Professors, vol. 66 (1), 1980, pp. 24-27.

[18] H. K. Wachtel, "Student evaluation of college teaching effect iveness: A brief review," in Assessment \& Evaluation in Higher Education, vol. 23(2), 1998, pp. 191-212.

[19] D. R. Long, "Second language listening comprehension: A schematheoretic perspective," in The Modern Language Journal, vol. 73(i), 1989, pp. 32-40.

[20] C. S. Chiang and P. Dunkel, "The effect of speech modification, prior knowledge, and listening proficiency on EFL lecture learning," in TESOT Quartery, vol. 26(2), 1992, pp. 345-374. 